\title{
IMPLEMENTASI PENDIDIKAN SENI DALAM MEMPERTAHANKAN KARAKTERISTIK BANGSA PADA GENERASI MILENIAL
}

\author{
Anik Purwati \\ SMA Negeri 4 Semarang \\ runikapu@gmail.com
}

\begin{abstract}
Social media is a vehicle that can be used to develop students' digital and modern creativity. The use of social media is certainly in line with the development of each generation with the characteristics of each generation. Millennials are a generation with significant technological change, must be able to face challenges, develop and be able to utilize technology without having to change its characteristics. There are four steps that must be taken to maintain the characteristics of the nation through art education: (1) having knowledge related to the learning climate in the classroom, (2) abilities relatedto learning management strategies, (3) having abilities related to providing feedback and strengthening, and (4) having abilities related to self-improvement
\end{abstract}

Keywords: Art Education, Characteristics of the Nation, Millennial Generation

\section{Pendahuluan}

Pendidikansecara umum merupakan pranata sosial yang kuat dan berwibawa untuk memberdayakan semua warga negara Indonesia berkembang menjadi manusia yang berkualitas sehingga mampu dan proaktif menjawab tantangan zaman yang selalu berubah.Adapun tujuan pendidikan, termasuk pendidikan seni: pertama, menyiapkan peserta didik untuk menjadi anggota masyarakat yang memiliki kemampuan akademik-profesional. Kedua, mengembangkan, menciptakan dan menerapkan ilmu pengetahuan, IPTEK dan seni. Ketiga, menyebarluaskan ilmu pengetahuan, IPTEK dan seni. Keempat, mengupayakan penggunaan ilmu pengetahuan, IPTEK dan seni untuk meningkatkan kualitas kehidupan masyarakat

Untuk mewujudkan tujuan pendidikan tersebut, ada beberapa hal yang dikedepankan oleh pendidikan. Pertama, mengupayakan perluasan dan pemerataan kesempatan memperoleh pendidikan yang bermutu bagi seluruh rakyat Indonesia.Kedua, membantu dan memfasilitasi pengembangan potensi anak bangsa secara utuh sejak usia dini sampai akhir hayat dalam rangka mewujudkan masyarakat belajar. Ketiga, meningkatkan kesiapan masukan dan kualitas proses pendidikan untuk mengoptimalkan pembentukan kepribadian yang 
bermoral.Keempat, meningkatkan keprofesionalan dan akuntabilitas lembaga pendidikan sebagai pusat pembudayaan ilmu pengetahuan. keterampilan, pengalaman, sikap, dan nilai berdasarkan standar nasional dan global.

Pendidikan seni salah satu bagian integral dari sistem pendidikan nasional berusaha mempertahankan karakteristik budaya bangsa di tengah globalisasi yang menggejala di Indonesia. Terlebih, peserta didik dunia pendidikan dewas ini adalah generasi millenial. Berbagai persoalan sosial pendidikan banyak muncul ketika dihadapan dengan modernita. Salah satunya adalah media sosial. mereka lebih suka melihat dan membaca media sosial dari pada buku. Maka pendidikan perlu ada terobosan baru agar proses pendidikan bisa mengena pada generasi millenial. Makalah ini mencoba memotret bagaimana cara pendidikan seni ikut berperan dalam menjaga karakteristik bangsa pada generasi milenial, dan bagaimana bentuk implementasi pendidikan seni dalam proses pembelajaran kelas pada generasi milenial.

\section{Pembahasan}

\section{Pendidikan Seni di Era Globalisasi}

Perkembangan jaman tentunya menuntut kita sebagai manusia untuk terus mampu menyeimbangkan kebutuhan dan kualitas kita sehingga mampu menghadapi tantangannya. Arus globalisasi yang menawarkan kemudahan dalam berbagai hal menjadikan manusia lena dalam kehidupan yang serba praktis, cepat, instan, dan digital. Hal ini tentunya menjadi tantangan tersendiri didunia pendidikan, terutama pendidikan seni dalam merespon perkembangan teknologi yang cepat.

Menurut Rohidi (2001: 73-74), pendidikan seni smerupakan bagian integral dari sistem pendidikan menyeluruh yang tercakup dari pendidikan formal. Karena itu, pendidikan seni dapat pahami sebagai usaha sadar dan terencana untuk menanamkan dan membentuk model-model pengetahuan (knowledge role models) yang menjadi worldview serta pedoman bagi pemenuhan kebutuhan keindahan dari individu atau kelompok masyarakat.Dalam pelaksanaannya, pendidikan seni selalu mempertimbangkan pula perkembangan fisik dan kejiwaan peserta didik, sehingga berbentuk/berubah perilakunya menjadi mampu berpikir, menghayati, menginterpretasikan, dan memanfaatkan sumber daya yang ada dalam lingkungannya untuk meningkatkan taraf kehidupan pribadi, masyarakat, serta bangsa. 
Sejalan dengan pengertian diatas, pendidikan seni dapat dipahami tidak hanya sebatas proses pengalihan kebudayaan (transfer of culture) dan pelestarian kebudayaan(engaging culture) saja. lebih dari itu, pendidikan seni merupakan sebuah proses pengembangan kebudayaan "development culture process" serta dikaitkan dengan dinamika perubahan dalam kelompok masyarakat dan kebudayaanya (Agustini, 2017:144).

Terlebih, jika pendidikan seni dikaitkan dengan era globalisasi, dimana semua aspek kehidupan manusia serba terhubung, mengdepankan monokultur, dan dunia menjadi kecil "global village," tentunya kita tidak cukup hanya mengedepankan pandangan satu arah (one perspective) saja, melainkan membutuhkan multiple approaches untuk memotret realitas pendidikan seni agar mendapat pemahaman secara utuh. Berbagai arah saling terkait dan saling tarik menarik menjadi sebuah pengertian tersendiri dalam sebuah fenomena kehidupan. Globalisasi diartikan sebagai pengaruh yang tidak bisa dicegah keberadaanya dan kemudian diterima; sesuatu yang sesungguhnya merupakan mistifikasi dari kesadaran budaya menjadi ideologi (Rohidi, 2016). Tantangan yang penting dan utama yang dihadapi adalah globalisasi yang meliputi ilmu pengetahuandidalamnya pendidikan seni, teknologi, informasi, ekonomi dan lain sebagainya.

Munculnya era globalisasi ini mengandung pengertian adanya ruang elektronik tak terbatas bagi sisi kehidupan manusia dalam mengekplorasi intelengensinya, dan itu menyebabkan hilangnya proses interaksi sosial masyarakat secara verbal. Harapanya melalui pendidikan seni dapat memberikan pemahaman sehingga memungkinkan masyarakat terutama peserta didik mampu mempertahankan karakteristik dan identitas jati diri (self identity) sebagai bangsa Indonesia.

Arus globalisasi ini merambah diberbagai lini kehidupan manusia, termasuk didalam implementasi pendidikan seni dilapangan. Kenyataanya, pemanfaatan teknologi dalam implementasi pendidikan seni di sekolah atau pendidikan formal sangat menbantu pemahaman dan penyampaian materi secara cepat dan efisien dengan berbagai tawaran contoh dan apikasi. Peningkatan kualitas pendidikan seni dengan pemanfaatan teknologi baik elektronik maupun mediasosial diharapkan menyempurnakan proses pembelajaran seni di sekolah tanpa mengesampingkan 
keutamaan karakteristik peserta didik baik secara individu maupun kelompok masyarakat.

\section{Karakteristik Generasi Milenial}

Segala aspek perubahan di era globalisasi membuat sekat-sekat karakteristik generasi manusia. Pada setiap generasi memiliki karakteristik masing-masing yang membentuk pola pikir, habit of mind, living tradition, dan kebiasaan generasinya secara menyeluruh dan membudaya, sehingga memunculkan ciri khas dan simbol generasi tersebut.Era globalisasi yang ditandai dengan munculnya internet yang membawa berbagai macam tawaran media sosial seperti, Facebook $(\mathrm{Fb})$, Whatshap (WA), Instagram (IG), youtube,Line, dan lain sebagainya, yang membantu manusia untuk menunjukkan identitas diri dan eksistensinya. Kemajuan peradaban manusia membawa dampak pada perilaku manusia dimana dulu dalam pencarian informasi masih meggunakan media elektronik dan media cetak seperti radio, TV dan koran. Kini manusia memanfaatkan kecanggihan dari teknologi media online dalam pencarian informasi sehingga cepat,akurat dan praktis(Panjaitan, 2017)

Berbicara tentang generasi milenial, tentunya kita tidak lepas dengan sekat generasi yang lain. Millenial adalah istilah cohort dalam demografi, merupakan kata benda yang berarti pengikut atau kelompok. Saat ini ada empat cohort besar dalam demografi, yaitu Baby Boomer (lahir pada tahun 1946-1964), generasi X (lahir pada tahun 1965-1980), millenial (lahir pada tahun 1981-2000) dan geberasi Z ( lahir pada tahun 2001-sekarang). Jadi generasi milenial pada saat ini (2018) adalah mereka yang berusia 18-37 tahun; yang kini berperan sebagai mahaiswa, early jobber dan orang tua muda (Walidah, 2017

sejalan dengan pemahaman diatas berikut ini disajikan matrik perkembangan generasi dengan karakteristiknya, sebagai berikut ; 


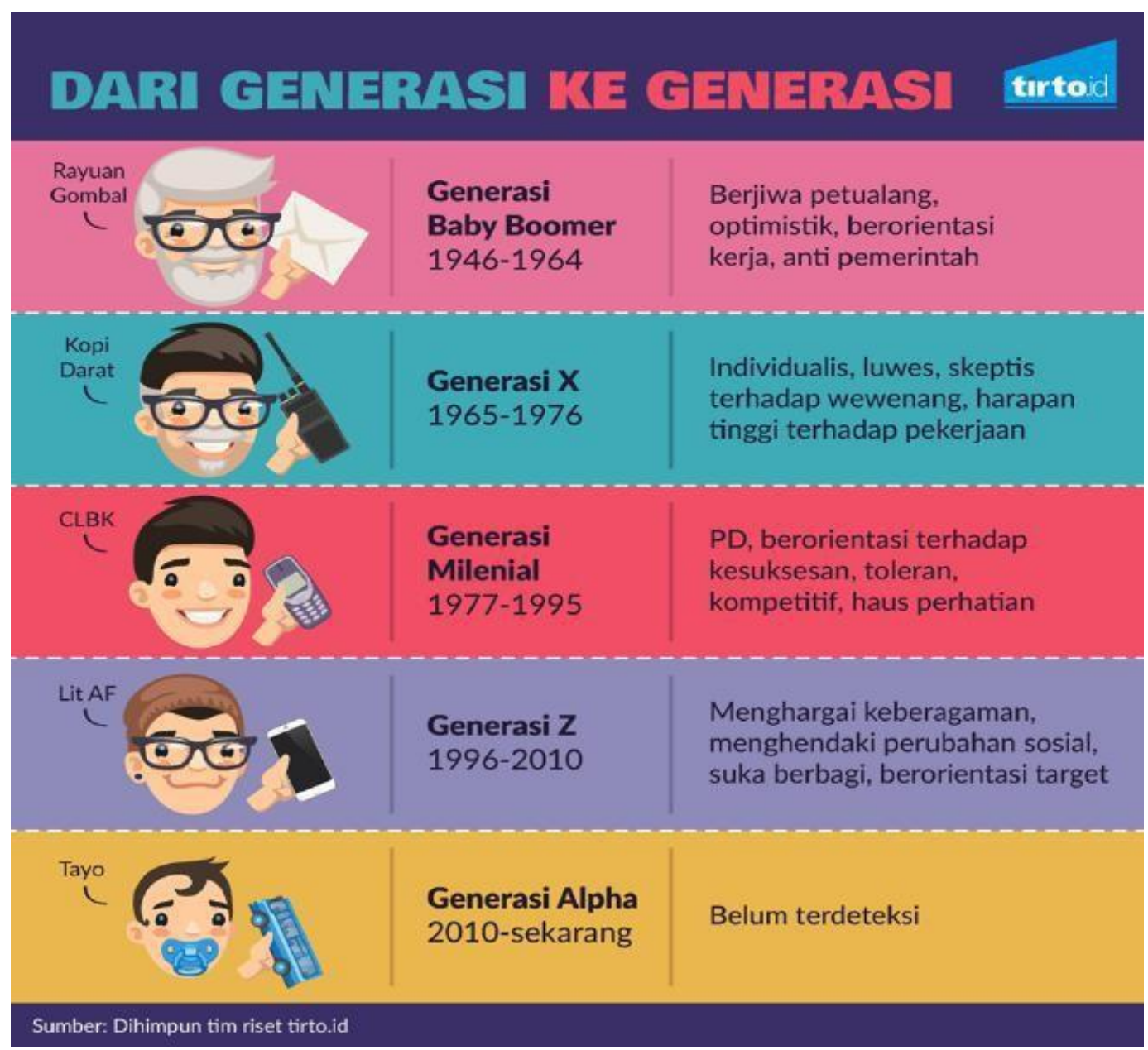

Gambar 1. Kelompok generasi dari Generasi Baby Boomer hingga Generasi Alpha(sumber: tirto.iddengan modifikasi dari tautan https://tirto.id/dari-generasi-kegenerasi-ctMX pada tanggal 20 November 2018

Adanya perbedaan kisaran tahun merupakan selisih yang tidak terlalu signifikasi dalam pembawaan karakteristik setiap generasi. Melihat gambar diatas menunjukkan karakteristik generasi milenial yang percaya diri, berorientasi terhadap kesusksesan, toleransi, kompetisi dan haus akan perhatian. Generasi ini mengalami perkembangan dari teknologi munculnya telepon rumahan sampai perangkat smartphone, dari radio sampai internet.

Menurut buku“Millennial Nusantara: Pahami Karakternya, Rebut Simpatinya" karangan Hasanuddin Ali danLilik Purwandi, generasi milenial di Indonesia memiliki 3 karakter utama: pertama, creative,cenderung berpikir keluar dari cangkang (out of the box). Salah satu buktinya adalah tumbuh dan berkembangnyaindustri startup dan industri kreatif lainnya yang dimotori oleh anak muda. Kedua, confidence, sangatpercaya diri, mereka sangat berani mengemukakan 
pendapat bahkan berdebat di mediasosial.Ketiga, connected, generasi ini sangat pandai berkomunikasi sehingga fasih menggunakanmedia sosial dalam mencari dan menjalin relasi (Ali \& Purwandi, 2017).

Berdasarkan karaktergenerasi milenial ini, maka perkembangan teknologi informasi akan menjadi salah satu alatbantu utama dalam berproses dan berperan dalam setiap sisi kehidupan sosial danpendidikan di era milenial (Gunanto, 2017).Pemahaman tentang karakteristik generasi milenial ini tentunya berpengaruh pada pemahaman akan pendidikan seni yang diterimanya selama di sekolah, dimana titik utamanya korelasi antara karakteristik generasi milenial dalam menggunakan teknologi untuk membantu implementasi pendidikan seni di sekolah.

\section{Implementasi Pendidikan Seni dalam Pembelajaran pada Generasi Milenial}

Implementasi pendidikan seni dalam era globalisasi membentuk pendidik harus kreatif dan dan selalu berpikir inovatif dalam pembelajaran kelasnya, hal ini diharapkan dapat mempermudah dalam penyampaian materi kepada peserta didik. Dengan kemajuan IPTEK, terutama medsos, pendidik bisa memafaatkan media sosial untuk kepentingan pendidikan. Hal ini akan semakin memudahkan dalam proses komunikasi antar manusia yang telah mengalami revolusi yang cukup signifikan dengan hadirnya internet sebagai bentuk media baru (new media). Fenomena ini bagi dunia pendidikan telah membentuk sebuah pola baru komunikasi antar pendidik dan peserta didik. McQuail (2011) menyatakan bahwa salah satu perubahan yang paling penting dalam kehidupan masyarakat adalah meningkatnya interaktifitas dan konektifitas antar manusia. Hadirnya media baru ini dinilai oleh Lister dkk. (2009) telah menawarkan keaktifan yang tidak bisa diberikan oleh media tradisional. Unsur interaktifitas menjadi dan dijadikan karakter utama bagi media baru.

Media sosial (social media) sebagai salah satu bentuk media baru menjadi fenomena pada dunia pendidikan di Indonesia dengan peningkatan jumlah pengguna yang sangat fantastis. Pendidikan seni bisa memanfaatkan media sosial untuk kepentingan proses pendidikan, misalnya dengan take video kemudian memberikan panduan dan men-share ke media sosial seperti Facebook, Instagram, Youtube, Line, dan lainnya. Beberapa kajian tentang motif penggunaan media sosial menunjukkan adanya variasi kepentingan yang disampaikan oleh pengguna 
ketika terkoneksi dengan internet. Motif tersebut antara lain mencari informasi alternatif, berkomunikasi dengan rekan jauh, atau sebagai ruang eksistensi diri. Secara konsep, peran dasar media sosial adalah untuk berbagi informasi, komunitas virtual, dan forum diskusi. Peran tersebut dapat dicapai karena sifatnya yang partisipatif, terbuka, mendorong percakapan, komunitas, dan keterhubungan antar pengguna.

Dari sudut pandang pendidikan, termasuk pendidikan seni, media sosial telah mempengaruhi tata cara manusia bersosialisasi, berteman, dan berinteraksi. Berdasarkan konsep sosiologi yang memandang masyarakat sebagai kelompok manusia yang menghasilkan kebudayaan, jika masalah ujaran kebencian di media sosial tidak dapat dikendalikan maka suatu saat akan dapat menjadi racun bagi perkembangan peradaban masyarakat. Masyarakat akan mengalami kemunduran moral yang membahayakan masa depan generasi muda. Masa depan apa yang akan didapatkan oleh anak-anak dan remaja yang sejak kecil telah menyaksikan dan/atau bahkan mengalami ujaran kebencian di media sosial. Oleh karena itu, kita perlu menyelamatkan generasi muda dari dampak ujaran kebencian di media sosial.

Media massa dan media sosial seharusnya dikembalikan pada tujuan awal, yaitu untuk memberikan informasi, pendidikan, dan hiburan bagi masyarakat, serta menjadi alat kontrol sosial bagi penyelenggaraan negara. Masyarakat yang harmonis hanya akan tercipta jika setiap orang Indonesia bersedia membangun komunikasi yang baik dengan sesamanya tanpa membuang sia-sia energi untuk meluncurkan ujaran kebencian yang dapat mencerai-beraikan anak-anak bangsa. Indonesia akan menjadi kuat dengan komunikasi yang positif di antara warganya. Media massa dan media sosial harus menjadi lembaga yang kuat dan bekerja secara profesional sedangkan masyarakat perlu terus belajar untuk berpikir logis dan tidak mudah terhasut oleh ujaran-ujaran kebencian di media massa dan media sosial.

Media sosial seperti FB merupakan ruang publik yang tidak bertuan, berita yang tidak mempunyai reporter, karena semua orang berhak dan bisa menjadi jurnalis dengan memposting sesuatu yang dianggapnya penting, meskipun hal tersebut berdampak negatif terhadap pengguna FB yang lain. Pola komunikasi dengan model media sosial FB ini bisa disebut sebagai "quasi communication" yang merupakan ruang semu, pengab, dan penuh tipu daya. Hal ini terlihat dari postingan di FB yang tidak memperhatikan tutur kata/ungkapan, orang selalu 
mempertimbangkan apakah tuturan tersebut tergolong sebagai tuturan yang santun ataukah tuturan yang tidak santun, terlebih jika memposting ujaran kebencian. Dengan demikian, dapat terjadi, jika tuturan yang digunakan kurang santun dan dapat menjadi lebih santun ketika tuturan tersebut ditata kembali. Artinya orang yang melakukan ujaran kebencian di media sosial seperti FB mengalami "split personality"-keterpecahan kepribadian, bahkan mereka mengalami gangguan psikis "sick soul" sehingga tanpa dipikir panjang mereka menyampaikan berita kepada komunikan tanpa mempertimbangkan dampaknya secara luas. Karena itu, untuk mengutarakan maksud tertentu, orang ketika bertutur biasanya mengubah urutan tuturannya supaya menjadi tegas, keras, dan bahkan menjadi tuturan yang kasar. Kenyataan tersebut tidak menyimpang dari yang dikatakan Hymes dengan konsep "speaking" dalam teori etnografi komunikasinya bahwa urutan tutur (actrs) untuk menentukan makna sebuah tuturan (Rahardi, 2005: 121).

Pendidikan seni menekankan adannya kesantunan dalam berbahasa merupakan kesantunan dalam menggunakan bahasa saat berkomunikasi lisan maupun tulis termasuk ketika menggunakan media sosial. Bahasa yang biasa digunakan untuk bertutur penuh dengan nilai-nilai kesopanan, kebanyakan manusia dapat meniru bahasa yang diucapkan, yang didengar dan yang dilihatnya, oleh karena itu salah satu yang dapat mempengaruhi kesantunan berbahasa seseorang yaitu media sosial instagram. Media sosial sangat mempengaruhi kesantunan berbahasa seseorang, seperti yang dilakukan oleh heaters dengan member komentar yang kasar terhadap video maupun foto yang diunggah oleh pemilik akun, sehingga menimbulkan pelanggaran prinsip kesopanan maupun kesantunan. FB adalah suatu jejaring sosial yang mempunyai tujuan untuk membantu penggunanya membagikan atau mengunggah foto kepada pengguna FB yang lainnya (Rahman, 2014). Media sosial seperti FB sebagai objek kajian karena media sosial tersebut yang paling popular saat ini. Terkait dengan kasus politik keagamaan yang mengarah pada "penistaan agama," banyak heaters yang melontarkan kata kasar di kolom komentar dan mengunggah foto di akun Fbnya.

Dalam konteks proses pembelajaran seni di kelas, Menurut Davis dan Thomas, ada beberapa hal yang bisa dilakukan: pertama, mempunyai pengetahuan yang terkait dengan iklim belajar di kelas yang mencakup: 1) keterampilan interpersonal khususnya kemampuan untuk menunjukkan empati, penghargaan terhadap peserta 
didik, dan ketulusan, 2) menjalin hubungan yang baik dengan peserta didik, 3) mampu menerima, mengakui dan memperhatikan peserta didik secara ikhlas, 4) menunjukkan minat dan antusias yang tinggi dalam mengajar, 5) mampu menciptakan atmosfir untuk tumbuhnya kerjasama dan kohesivitas dalam dan antar kelompok peserta didik, 6) mampu melibatkan peserta didik dalam mengorganisir dan merencanakan kegiatan pembelajaran, 7) mampu mendengarkan peserta didik dan menghargai haknya untuk berbicara dalam setiap diskusi, 8) mampu meminimalkan friksi-friksi di kelas.

Kedua, kemampuan yang terkait dengan strategi manajemen pembelajaran, yang mencakup : 1) mempunyai kemampuan untuk menghadapi dan menanggapi peserta didik yang tidak mempunyai perhatian, suka menyela, mengalihkan perhatian, dan mampu memberikan transisi substansi bahan ajar dalam proses pembelajaran; 2) mampu bertanya atau memberikan tugas yang memerlukan tingkatan berpikir yang berbeda untuk semua peserta didik.

Ketiga, mempunyai kemampuan yang terkait dengan pemberian umpan balik dan penguatan yang terdiri atas : 1) mampu memberikan umpan balik yang positif terhadap respon peserta didik; 2) mampu memberikan respon yang bersifat membantu terhadap peserta didik yang lamban dalam belajar; 3) mampu memberikan tindak lanjut terhadap jawaban peserta didik yang kurang memuaskan;

4) mampu memberikan bantuan profesional kepada peserta didik jika diperlukan. Keempat, mempunyai kemampuan yang terkait dengan peningkatan diri yang mencakup : 1) mampu menerapkan kurikulum dan metode mengajar secara inovatif; 2) mampu memperluas dan menambah pengetahuan mengenai metode- metode pembelajaran; 3) mampu memanfaatkan perencanaan guru secara berkelompok untuk menciptakan dan mengembangkan metode pembelajaran yang relevan (Suyanto, 2001:3).

\section{Kesimpulan}

Dalam menjawab tantangan jaman untuk generasi yang semakin maju diperlikan guru yang kreatif dan inovatif dengan memanfaatkan media teknologi yang serba digital, sehingga anak dapat menguasai materi dengan sangat cepat dan optimal. Penggunakan metode-metode pembelajaran yang menyenangkan dan 
perkembangan teknologi yang luar biasa dapat menciptakan suasana pembelajaran yang kondusif dan menyenangkan.

\section{Daftar Pustaka}

Supriyanto, Joko. 2011. Cooperative Learning; Teori Dan Aplikasi PAIKEM. Pustaka Pelajar. Yogyakarta.

Triyanto. 2017. Spirit Ideologi Pendidikan Seni. Cipta Prima Nusantara. Semarang.

Rohidi, Tjetjep Rohendi. 2014. PENDIDIKAN SENI; Isu Dan Paradigma. Cipta Prima Nusantara. Semarang

Zulfanah, Amir Faizal. 2012. Pendidikan Karakter 88 \%. Duta Publushing Indonesia.

Irawan, Deddy. 2017. Paradigma Pendidikan Seni. Thafa Media. Yogyakata. 